\title{
Direct analysis of vicariance in Neotropical mayflies (Ephemeroptera)
}

\author{
CARLOS MOLINERI, CAROLINA NIETO and EDUARDO DOMÍNGUEZ
}

\author{
Instituto de Biodiversidad Neotropical, CONICET, Universidad Nacional de Tucumán, Facultad \\ de Ciencias Naturales, Ciudad Universitaria, 4107, Horco Molle, Tucumán, Argentina \\ Manuscript received on November 1, 2018; accepted for publication on February 2, 2019
}

\begin{abstract}
How to cite: MOLINERI C, NIETO C AND DOMÍNGUEZ E. 2019. Direct analysis of vicariance in Neotropical mayflies (Ephemeroptera). An Acad Bras Cienc 91: e20181130. DOI 10.1590/0001-3765201920181130.
\end{abstract}

\begin{abstract}
The distribution of aquatic insects has been poorly explored in quantitative analyses aiming at the historical reconstruction of area relationships in the Neotropics. Ephemeroptera is an ancient group, characterized by its low vagility, and of high richness and endemicity in this region. Systematic knowledge of the group has enormously increased in the last decades, achieving a sufficient background to explore biogeographical historical patterns. Our aim is to reconstruct area history in the Neotropics using the rationale of Barrier biogeography (Hovenkamp protocol). We present eleven mayfly phylogenies, representing groups that evolved independently at least from the Jurassic (i.e., not a one-taxon history). With these groups, we conducted independent biogeographical analyses (using Vicariance Inference Program), and extracted the events that repeated in two or more clades. We found fifty-eight TVEs (Traceable Vicariant Events), from which four were found at least twice, thus constituting SVEs (Supported Vicariant Events).
\end{abstract}

Key words: historical biogeography, South America, Neotropical, phylogeny, taxon history.

\section{INTRODUCTION}

Vicariance is one of the most frequently reported historical processes explaining large-scale biogeographical patterns since Croizat (1958) vigorously defended the concept. Much debate and many methods have dealt with the way in which area and organism distribution should be studied to identify vicariance (e.g., Hennig 1966, Brundin 1966, Rosen 1978, Nelson and Platnick 1981, Brooks 1990, Ronquist 1997, Hausdorf and Hennig 2003, Ebach and Williams 2016). Much of the problems of the methods rely on the way areas are delimited (Hovenkamp 1997, 2001, Hausdorf 2002, Ferrari

Correspondence to: Carlos Molineri

E-mail: carlosmolineri@gmail.com

ORCid: https://orcid.org/0000-0003-2662-624X
2018). A priori delimitation of areas from previously proposed classifications (geographical, geological, ecological, or biogeographical) is the most common procedure in DIVA (Ronquist 1997), S-DIVA (Yu et al. 2010), DEC (Dispersal-Extintion-Cladogenesis Model, Ree and Smith 2008), PAE (Morrone and Crisci 1995), and cladistic biogeography (Nelson and Platnick 1981). The simple and powerful proposal of Hovenkamp (1997, 2001) overcomes this problem, by focusing on the barrier separating two putative vicariant areas. Using a cladogram and the distribution of its terminals, Hovenkamp (1997) proposed a protocol to detect traceable vicariance events (TVEs), comparing the distribution of all sister taxa. Comparing the information from different taxa, supported vicariance events (SVEs) would ideally be found. This protocol was partially implemented by 
Arias (2010) and Arias et al. (2011), facilitating the analysis of complex datasets. Such implementation (VIP, Vicariance Inference Program, Arias 2010) deals with taxon history, thus we separately analyzed the different groups, to recover their shared patterns in a subsequent step as done by Domínguez et al. (2016).

The Neotropical region has been studied from an historical biogeographical perspective at many scales and based on different taxa. The Neotropical region, as defined by Morrone (2014a, b), includes most of tropical and subtropical South America, Central America, part of Mexico, and the Antilles. Mayflies are remarkable due to being an ancient group with poor dispersal capabilities (Edmunds 1972, Dos Santos et al. 2018), that might offer interesting information about the history of the Neotropics, as has been proved in other areas (Barber-James et al. 2008, Selvakumar et al. 2014, Gattolliat et al. 2015).

Different studies deal with mayfly historical biogeography at large scales, comparing biotas from different biogeographical regions: e.g. Nearctic, Neotropical, Andean-Patagonian (Edmunds 1972, Savage 1987, McCafferty 1998, Barber-James et al. 2008, Flowers and Ávila 2006, Flowers 2009). Mayfly studies focusing on Neotropical fauna have greatly increased in the last two decades (Shimano et al. 2013, Domínguez and Dos Santos 2014), and as a result, many phylogenies and new distributional data are now available to explore different biogeographical processes that have taken place in the area.

The aim of the present paper is to identify vicariant events in the Neotropics using different mayfly taxa (i.e., to reconstruct the history of the areas). To reach this objective, we selected eleven phylogenies representing groups that evolved independently from each other at least from the Jurassic (Ogden et al. 2009, Staniczek et al. 2011): Leptophlebiidae (Farrodes Peters 1971 and Simothraulopsis Demoulin 1966),
Oligoneuriidae (Oligoneuria Pictet 1843), Baetidae (Baetodes-complex and Callibaetis Eaton 1881), Leptohyphidae (Allenhyphes-Traverhyphes group), Polymitarcyidae (Asthenopodinae, Campsurus Eaton 1868, Tortopus Needham and Murphy 1924 and Tortopsis Molineri 2010), and Caenidae (Brasilocaenis Puthz 1975).

\section{MATERIALS AND METHODS}

Publications referring to Neotropical mayfly phylogenies at the species level were selected. Character matrices were updated, including the following new species or new life stages described since their original publication: 1) Baetodes complex (Baetidae), 15 species from eight genera and Baetodes treated at the genus level (Nieto 2016, 1 species added here, see below); 2) Callibaetis (Baetidae), 37 species, including 28 species of the genus (Cruz et al. 2017); 3) Brasilocaenis and Caenis (Caenidae), 20 species (Lima et al. 2019); 4) Simothraulopsis (Leptophlebiidae), 14 terminals including 9 species of the genus (Nascimento et al. 2017); 5) Farrodes (Leptophlebiidae), with 23 species (Domínguez 1999, Domínguez and Zuñiga 2009); 6) Allenhyphes-Traverhyphes group (Leptohyphidae), 21 species (Molineri 2004) and 2 additional species included here; 7) Oligoneuria (Oligoneuriidae), 12 species (Salles et al. 2014), of which one was described later (Massariol and Cruz 2015) and was added here; 8) Asthenopodinae (Polymitarcyidae), 17 species (Molineri et al. 2015); 9) Campsurus alfibilum and major groups (Polymitarcyidae), 13 species (Molineri and Salles 2013); 10) Tortopus (Polymitarcyidae); and 11) Tortopsis (Polymitarcyidae) both from Molineri (2010), with 21 species (plus 2 species included here).

The present study deals with 197 species and 3554 geographic records in total. Table I summarizes the information regarding the studied datasets. 
TABLE I

Data included in this study. 1 = number of species included in the original phylogeny, and number of species newly here incorporated (in brackets), 2 = total number of geographical records, 3 = number of TVEs found by VIP.

\begin{tabular}{ccccc}
\hline Taxon & species $^{\mathbf{1}}$ & records $^{2}$ & TVEs found $^{3}$ & Reference $^{\text {(n) }}$ \\
\hline Farrodes & 23 & 276 & 7 & Domínguez 1999, Domínguez and Zúñiga 2009 \\
Asthenopodinae & 17 & 449 & 6 & Molineri et al. 2015 \\
Brasilocaenis & 20 & 354 & 7 & Lima et al. 2019 \\
Oligoneuria & $11(1)$ & 74 & 4 & Salles et al. 2013 \\
Callibaetis & 37 & 761 & 14 & Cruz et al. 2017 \\
Campsurus & 13 & 110 & 2 & Molineri and Salles 2013, 2017 \\
Allenhyphes complex & $21(2)$ & 417 & 4 & Molineri 2004 \\
Baetodes complex & $15(1)$ & 620 & 5 & Nieto 2016 \\
Simothraulopsis & 14 & 287 & 4 & Nascimento et al. 2017 \\
Tortopsis and Tortopus & $21(2)$ & 208 & 5 & Molineri 2010 \\
Total & 197 & 3554 & 58 & \\
\hline
\end{tabular}

\section{PHYLOGENETIC SEARCHES}

The phylogenetic matrices of each of the selected studies were edited to a format readable in TNT (Goloboff et al. 2008) (available at https://ibn. conicet.gov.ar/recursos/AABC_SMat1-2). Some of them were modified to include new species described after their publication (Table I): in the Baetodes complex Moribaetis mimbresaurus McCafferty (2007) was added, in the AllenhyphesTraverhyphes group (Molineri, 2004), Lumahyphes cocal Boldrini et al. (2015), and Traverhyphes (T.) frevo Lima et al. (2011) were added, and in the Tortopus-Tortopsis matrix (Molineri, 2010), Tortopsis canum Gonçalves et al. (2011), and Tortopus ipixuna Molineri et al. (2012) were added. Finally, new information was added to the Campsurus matrix (Molineri and Salles 2013) regarding female adult and egg stages recently described (Molineri and Salles 2017) for $C$. amapaensis Molineri and Emmerich (2010). Following the settings and searches in each of the published phylogenies, all trees were obtained in TNT and saved in xml format using the "toxml" file provided in VIP (Arias 2010). When more than one shortest tree was recovered, strict consensus was used, except for Tortopsis, where a combinable component consensus was preferred. Clade support was calculated using 250 replicates of Jackknife with symmetric resampling (Goloboff et al. 2003) in TNT.

\section{BIOGEOGRAPHICAL ANALYSIS}

Geographic records of all the treated species were included in separate files for each group (available at https://ibn.conicet.gov.ar/recursos/AABC_SMat1$2)$. Records from the species inside the focal area (Neotropical region, as delimited in the shapefile from Löwenberg Neto 2014) are exact points of occurrence obtained in the field, and copied directly from the material section of taxonomic papers, or from the labels in the vials. Each species record from our focal area was checked for accuracy of their taxonomic identification and geographical location. Doubtful data (i.e., outliers mostly due to erroneous identifications) were not included. For species outside of our focal area (e.g., Nearctic, Palearctic, Ethiopian or Oriental regions) only approximate locations were included (centroids of states, departments or counties). Most of them were extracted from the literature or regional faunistic lists. 
The phylogenetic trees and geographical information of each group were studied independently in the VIP program (Arias 2010). A $1 \times 1$-degree grid was created, and for comparative purposes, $2^{\circ} \times 2^{\circ}$ and $5^{\circ} \times 5^{\circ}$ grids and different grid origins were also explored. The maximum fill option was not used, since it was considered risky to assume presence around the real data, especially with aquatic organisms, for which only observed records were analyzed. The default VIP reconstruction was used (OR reconstruction), this option was preferred because it considers all the input data (other type of VIP reconstructions delete terminals or partial distributions to find more "vicariance"). A maximum overlap of $10 \%$ in the ranges of sister pairs (i.e., a small superposition of two sister groups is tolerated and they are still considered as allopatric) was allowed. A vegetation map was used to show the results (downloaded from https://neo.sci.gsfc.nasa.gov/ view.php?datasetId=MOD_NDVI_M).

Hovenkamp's (1997) protocol was implemented to search vicariant patterns supported by different groups. VIP analyzes this for each individual phylogeny, and the comparison between different phylogenies is not implemented in a computer program, having to be done by direct comparison of the resulting maps (Domínguez et al. 2016). All the maps showing the distribution of disjunct sister pairs were saved as "jpg" images, and compared to identify similar events (TVEs). Subsequently, these TVEs were ordered in the time-frame provided by the phylogenetic tree (some events appear later than others in the phylogenies). Events appearing two or more times in different phylogenies were marked as SVEs. It is worth remarking that vicariant sister clades shown in figures are separated by a white line, to be used as a visual reference (i.e., it does not imply a barrier). Finally, the historical order of the SVEs was searched. Any given barrier can appear in the same place more than once, thus, two similar TVE's may be indicating different histories (i.e., they do not belong to the same time slice) (Hunn and Upchurch 2001). We attempted to reduce this methodological weakness by comparing the rank of the descendants (sister species, sister species groups, etc.) when different cladograms are compared, or by taking into consideration the position on the tree (when the same event appears more than once in the same cladogram).

\section{RESULTS}

Fifty-eight traceable vicariant events (TVEs) were recognized in all the analyzed datasets, of which most showed high (jackknife $>50$ ) support (Table I, Figs. S1-S10, available at https://ibn.conicet.gov. ar/recursos/AABC_SFigs), and four were found at least twice, thus constituting Supported Vicariant Events (SVE, Figs. 1-4).

The SVEs are roughly grouped in two sets: 1) one including continental South America (SVE1 and SVE2), and 2) another set involving North, Central and South America (SVE3 and SVE4).

SVE1 involves the separation of southeastern Venezuela and adjacent Brazil highlands from the tropical lowlands (Fig. 1a-c). SVE1 is supported by three TVEs: Fittkauneuria Pescador and Edmunds (1994) vs Oligoneuria, Caenis tepuiensis Molineri et al. (2011) vs C. cuniana Froehlich (1969) and Spiritiops tepuiensis Nieto and Derka (2012) vs $S$. silvudus Lugo-Ortiz and McCafferty (1998).

SVE2 (Fig. 2a-g) separates southern AtlanticParanaense and eastern Pampa (excluding the Argentine portion) from northern tropical areas (Amazonas and/or central and northern Atlantic forest). The barrier is located around latitude $22-23^{\circ} \mathrm{S}$. This SVE2 is the most frequent, and is supported by seven TVEs, in the following sister clades: Asthenopodes chumuco Molineri et al. (2015) vs A traverae Molineri et al. (2015) + A. picteti Hubbard (1975), Campsurus amapaensis vs $C$. major Needham and Murphy $(1924)+C$. argentinus Esben-Petersen (1912), Homothraulus 


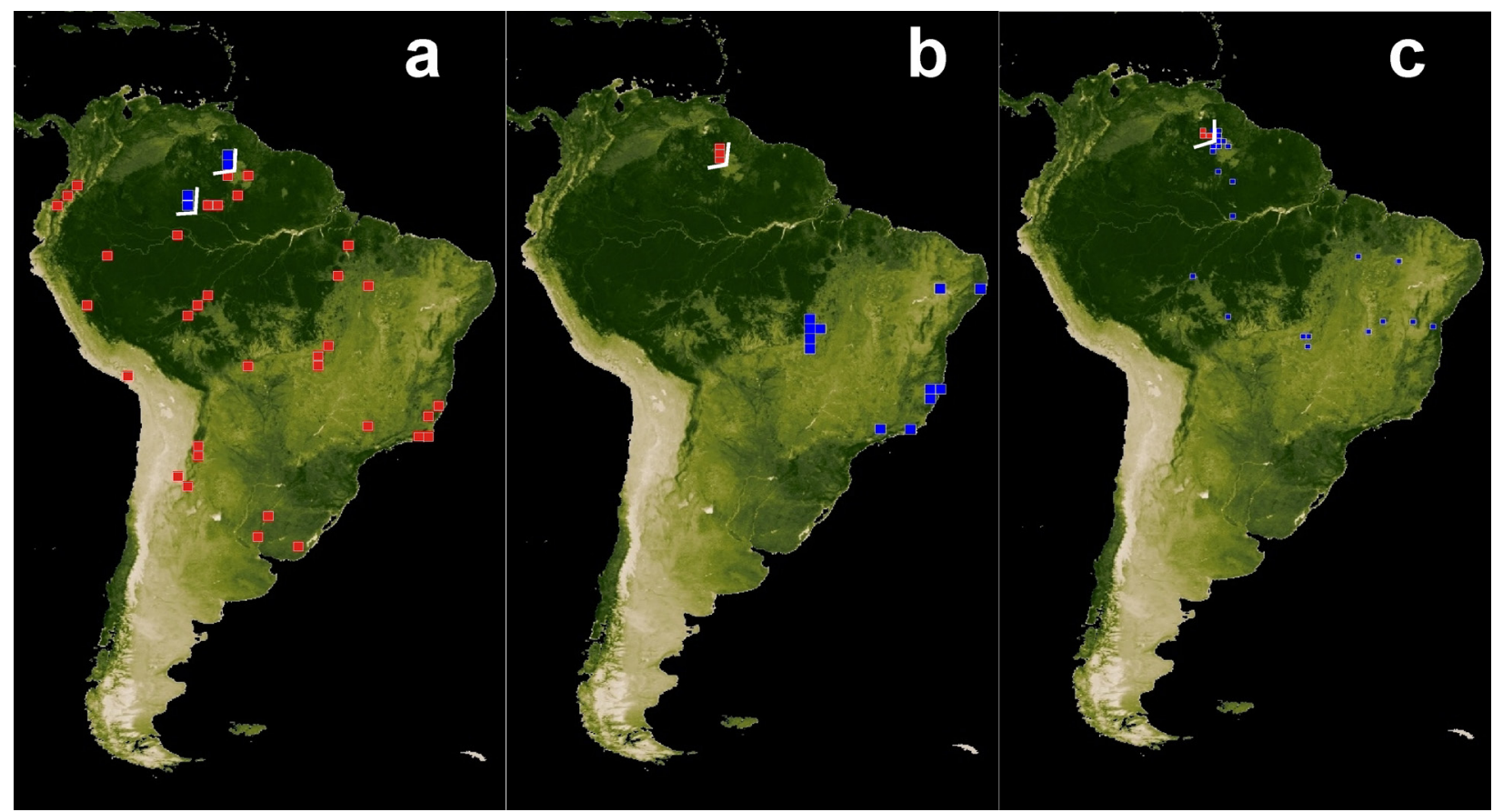

Figure 1 - SVE1 (Supported Vicariant Event 1): (a) Fittkauneuria (blue) and Oligoneuria (red); (b) Caenis tepuinensis (red) and Caenis cuniana (blue); (c) Spiritiops tepuinensis (red) and S. silvudus (blue). White lines are for visual reference (they are located in the same place in all the maps).

vs Simothraulopsis, Callibaetis (three times) and Caenis gaucha Lima et al. (2015) vs C. chamie Alba-Tercedor and Mosquera (1999).

SVE3 (Fig. 3a-d) involves the separation of North and South America. The limit includes the Panama isthmus, but the separation area of the sister pairs is more extended. This pattern is sustained by four TVEs: Farrodes texanus Davis (1987) vs F. maculatus (Needham and Murphy 1924), Callibaetis willineri Navas (1932) vs C. pretiosus Banks (1914), Callibaetis floridanus Banks (1900) vs C. gonzalezi (Navas 1934) and Tortopus bellus Lugo-Ortiz and McCafferty (1996) vs. the rest of the genus.

SVE4 (Fig. 4a-b) separates southern Mexico from Central America + northern South America in the Gulf of Honduras, and is supported by two TVEs: Farrodes tulija Domínguez et al. (1996) vs F. Alavipennis Domínguez et al. (1996), and F. maya Domínguez (1999) vs F. caribbianus (Traver 1943).

\section{DISCUSSION}

Mayflies were shown to be useful in detecting vicariant events in the New World, and particularly in South America, indicating fifty-eight (58) vicariant events. SVE1 (Supported Vicariant Event 1) involves the Tepuis-lowland vicariance. The age of Tepuis rocks has been dated on 1800$1600 \mathrm{Ma}$ (Brewer-Carías and Audy 2011), but the separation of both biotas occurred much recently, after the erosion of the sediments surrounding the actual tepuis or from recent migrations (Rull 2004). Mayflies supporting this vicariant pattern may be indicating two different events (i.e., different time slices), since the taxonomic level of the sisters (i.e., genus) found for Oligoneuriidae (Fig. 1a) may indicate a much older origin of the barrier than that of the two other sister groups involved (Caenis and Spiritiops Lugo-Ortiz and McCafferty 1998, at species level, Fig. 1b-c). Furthermore, the barrier is more complex in Oligoneuriidae. We hope that future research dating the sister clades could test 

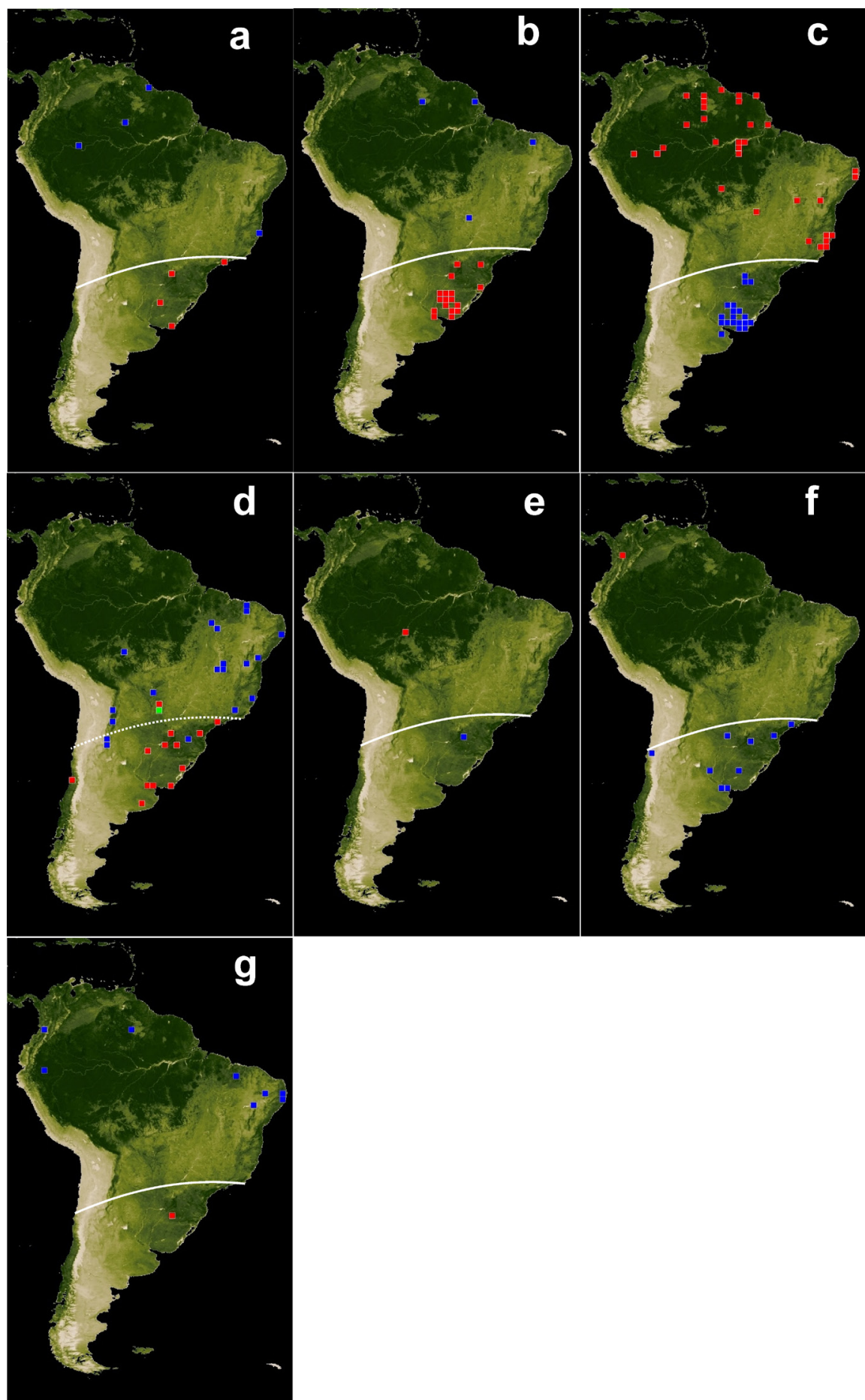

Figure 2 - SVE2 (Supported Vicariant Event 2): (a) Asthenopodes chumuco (blue) and $A$. traverae $+A$. picteti (red); (b) Campsurus amapaensis (blue) and C. major $+C$. argentinus (red); (c) Homothraulus (blue) and Simothraulopsis (red); (d) Callibaetis sellacki $+\mathrm{C}$. fasciatus (red) and C. pollens $+C$. dominguezi $+C$. capixaba $+C$. cochlea (blue); (e) Callibaetis itannae (red) and C. calophenigyn (blue); (f) Callibaetis molinerii (red) and C. jocosus (blue); (g) Caenis gaucha (red) and C. chamie (blue). White lines are for visual reference (they are located in the same place in all the maps). 
these hypotheses, nevertheless some studies have estimated divergence in mayfly sister species ranging 3 to 9 Mya (Sekiné et al. 2013, Bisconti et al. 2016). Zelusia Lugo-Ortiz and McCafferty (1998), with two described species, presents a similar vicariant pattern (Salles et al. 2016). Two conflicting hypotheses have been proposed to explain patterns of the Pantepui region: the idea of evolution in isolation obtained support from Oligoneuriidae, while the vertical displacement hypothesis (Desamore et al. 2014) would explain the other mayfly vicariants at species level.

SVE2, the south / north separation of subtropical from tropical areas around $22^{\circ}-23^{\circ} \mathrm{S}$ latitude, is the most repeated pattern found in the present work. The pattern is not coincident with present river basins, neither with repeated marine introgressions during the Miocene (marine barriers occurred predominantly through Plata-Paraná lowlands) (Rapela et al. 2007). The majority (but not all) of the TVEs supporting this SVE2 present one of the sisters restricted to Uruguay+ Misiones + south Brazil). The latter pattern roughly coincides with Rio de la Plata craton (Rapela et al. 2007, Gaucher et al. 2011), an ancient ArchaeanPalaeoproterozoic craton (1200-2100 Ma), now covered by newer formations (Almeida et al. 2000). Oldest mayflies are much younger (ca. $300 \mathrm{Ma}$, Staniczek et al. 2011), thus the pattern might be due to other events. Whether the area might have offered continuing suitable habitats (running waters) during part of the evolution of South American mayflies deserves further analysis. This area, now dominated by grasslands mixed with shrubs and forests, is frequently referred to as Brazilian Campos, occupies a transitional zone between tropical and temperate climates, and is characterized by cool winters and hot summers, with an absence of a dry season (Overbeck et al. 2007). Amorim and Pires (1996) recognized this region as an area of endemism (NE Argentina / southern Brazil), Overbeck et al. (2007) for example mention 95 endemic species of plants and animals.

SVE3, supported by four TVEs, corresponds to one or more different events of connection and isolation of the South American plate before the formation of the Panama isthmus (3 to $15 \mathrm{Ma} \mathrm{BP}$, Keigwin 1982, Montes et al. 2012, O'Dea et al. 2016). When disjunction patterns are markedly distant (e.g., Fig. 3a-c), an alternative explanation is long distance dispersion (Hovenkamp 1997). Thus, the vicariant explanation for this SVE3 would support the fact that the area of current Central America before the formation of the isthmus served as a corridor (i.e., allowing range expansion) for the ancestor of the four sister pairs supporting this SVE3 (Farrodes texanus - F. maculatus, Callibaetis willineri - C. pretiosus, Callibaetis floridanus - $C$. gonzalezi, Tortopus bellus - remaining Tortopus species), but later acted as a barrier that isolated both sisters. Farrodes, Callibaetis and Tortopus are species-rich genera, with much of their diversity in the Neotropics (Domínguez 1999, Molineri 2010, Cruz et al. 2017), which led McCafferty (1998) to hypothesize their South American origin and subsequent dispersal to Central and North America. Our analysis for Callibaetis and Tortopus shows that all basal clades are distributed in South America, coinciding with its putative southern origin (McCafferty 1998). Domínguez (1999) area cladograms show Central America and Northern South America as ancestral areas for Farrodes. Three of the TVEs involve species pairs (Farrodes and Callibaetis), but one (Tortopus) is due to a basal splitting in the genus, thus indicating a likely older occurrence (i.e., different time slices). However, younger events may explain Farrodes and Callibaetis TVEs: a recent (after the formation of the Panamanian land bridge) $\mathrm{S}$ to $\mathrm{N}$ dispersion of their ancestral species, followed by the sister's differentiation. An older vicariance between emergent land masses, prior to the final uplift of the isthmus should explain the pattern in Tortopus, 

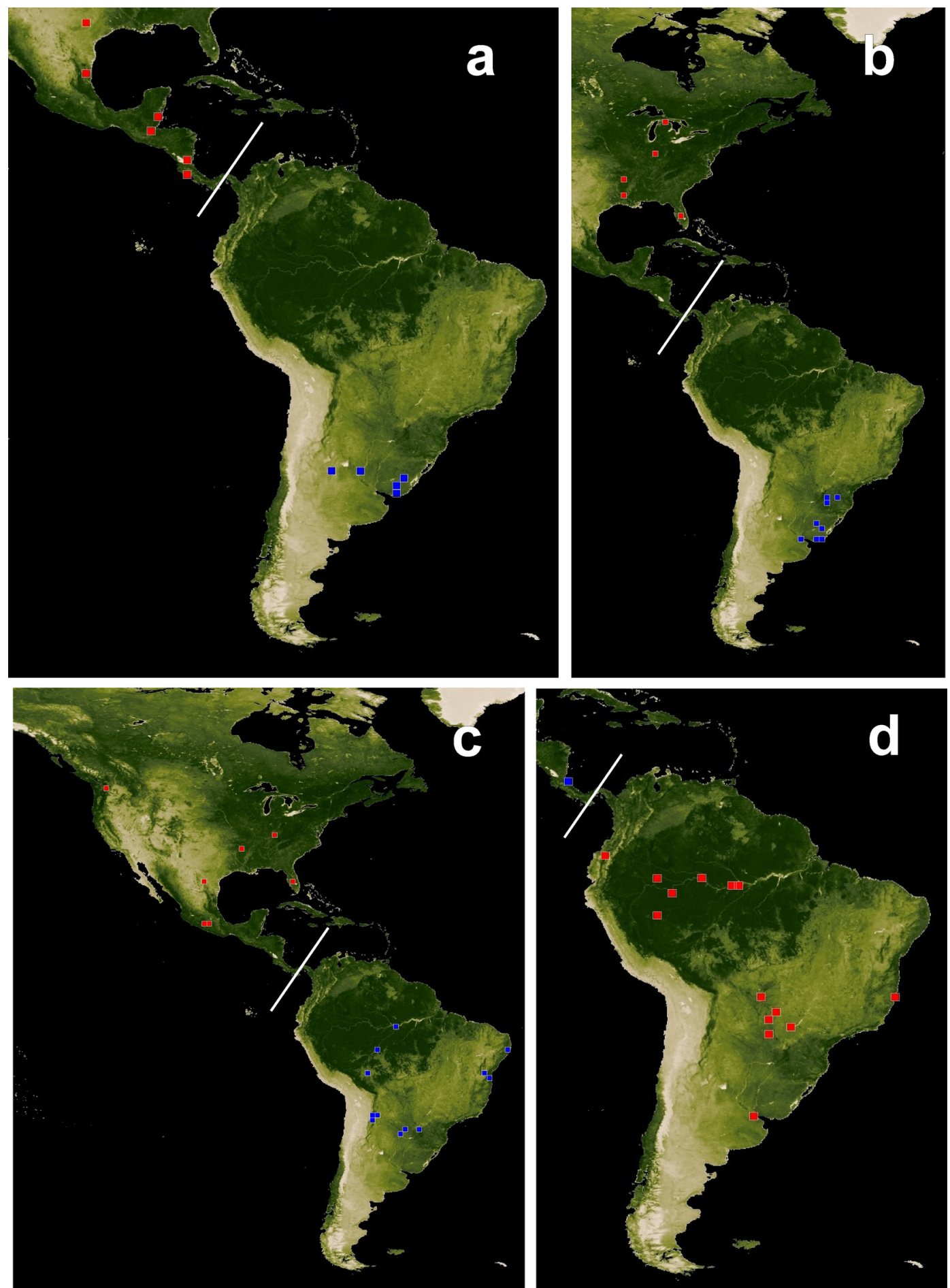

Figure 3 - SVE3 (Supported Vicariant Event 3): (a) Farrodes texanus (red) vs F. maculatus (blue); (b) Callibaetis willineri (blue) vs C. pretiosus (red); (c) Callibaetis floridanus (red) vs C. gonzalezi (blue); (d) Tortopus bellus (blue) vs rest of the genus (red). White lines are for visual reference (they are located in the same place in all the maps). 


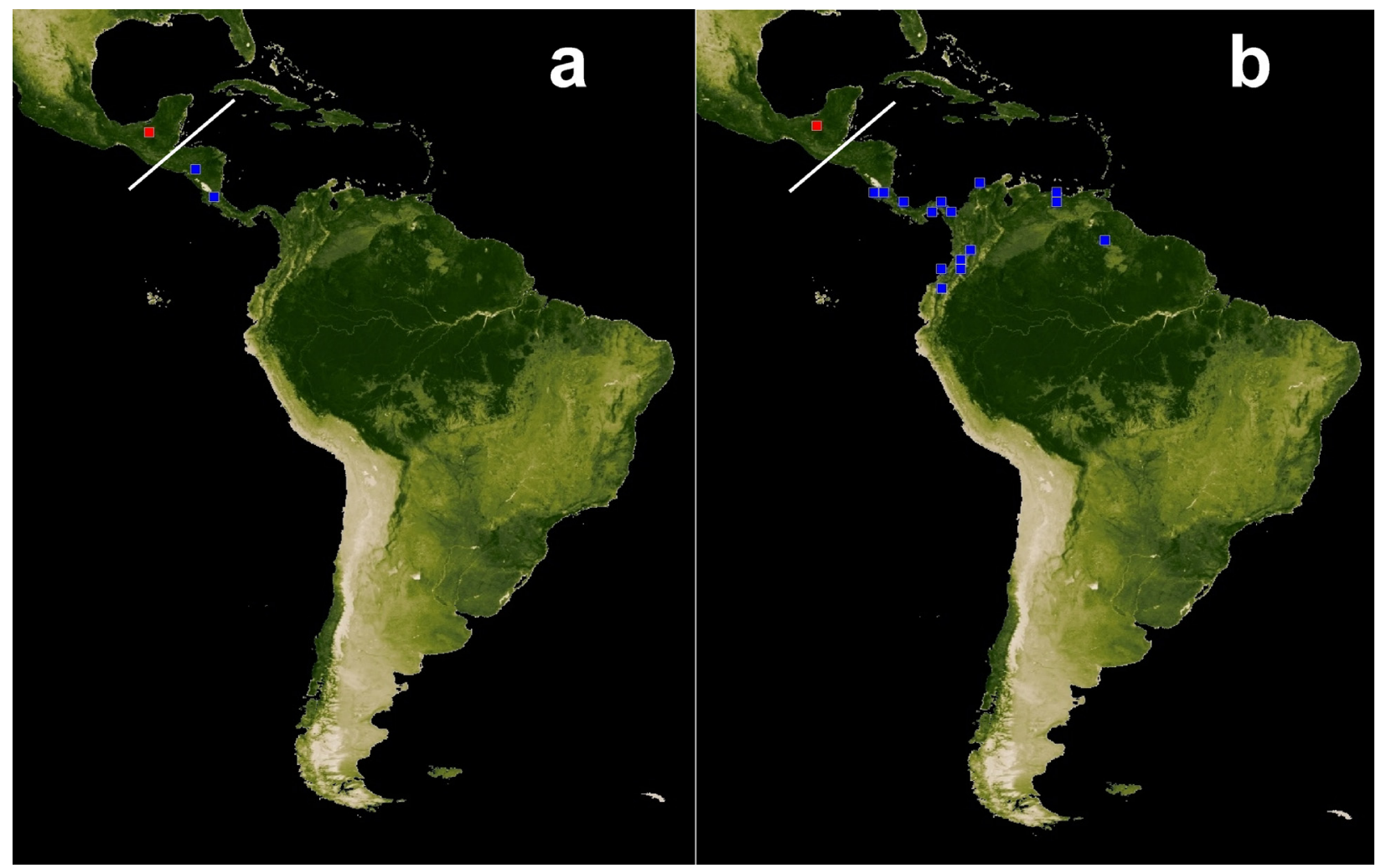

Figure 4 - SVE4 (Supported Vicariant Event 4): (a) Farrodes tulija (red) and F. flavipennis (blue); (b) F. maya (red) and F. caribbianus (blue). White lines are for visual reference (they are located in the same place in all the maps).

by one of these two known processes in the area: 1) the old Cretaceous-Palaeocene proto-Antilles land bridge (72Ma); or 2) the mid-Cenozoic Greater Antilles-Aves Ridge land bridge (GAARlandia, 34Ma) plus the Miocene Middle American land bridge (Říčan et al. 2013). Due to its age, the much older physical connection between North and South America occurring until mid-Jurassic (170 Ma) is excludable.

SVE4 is supported by two TVEs in Farrodes (Farrodes tulija - F. flavipennis, and F. maya - F. caribbianus), the barrier is located in the area of to the Gulf of Honduras, between the Chortis and Maya blocks (Iturralde-Vinent and MacPhee 1999). In the case vicariance is the underlying process originating these patterns, ancient events are to be invoked (170-148 Ma, Iturralde-Vinent and MacPhee 1999), which is inconsistent with the low taxonomical level of the pattern. Instead, the quaternary fragmentation of forest habitats (Haberle and Maslin 1999), where most species of the genus live, most likely explains this pattern.

We did not find any chronological order for the SVEs. We only found ordered TVEs, but some of them could shed light to the time frame involved. For example in the phylogeny of Asthenopodinae, a basal TVE1 (Fig. S3, available at https://ibn. conicet.gov.ar/recursos/AABC_SFigs) coinciding with the opening of the Atlantic Ocean, results in a minimum age of less than $110 \mathrm{Ma}$ (San Martín and Ronquist 2004) for the other TVEs in the mentioned phylogeny (e.g., TVE27 is similar to SVE2).

Other TVEs (i.e., unique events in our data) are mirrored in other taxa, or match hypothesized geological reconstructions, thus deserving further mention. We are aware that a greater taxa (and phylogeny) sampling would have led to support of these TVEs from other groups, for them to reach 
the status of SVE. For example, TVE6 and TVE41, occurring in Tortopsis (Fig. S9, available at https:// ibn.conicet.gov.ar/recursos/AABC_SFigs) partly coincide with vicariants in Atopophlebia Flowers, with a first barrier attributable to the Romeral fault (Flowers 2012) and a later barrier separating species in the upper Amazonas or Orinoco. Another pair of interesting TVEs involves Allenhyphes Hofmann and Sartori and Yaurina Molineri (TVE22 and TVE23). TVE22 (Fig. S6, available at https://ibn.conicet.gov.ar/recursos/AABC_SFigs) separates the Chocó, Caribbean and Central-North American regions (where Allenhyphes is found) from the central Andes (Ecuador to Argentina, Yaurina distribution). TVE23 (Fig. S6, available at https://ibn.conicet.gov.ar/recursos/ AABC_ SFigs) shows the splitting of Allenhyphes in a northern (north to Honduras Gulf) and southern species (in Costa Rica, Lesser Antilles, Choco and Maracaibo). These patterns seem to be due to the complex evolution of the area, with many bridges and terrane accretions acting consecutively around current Central America (Meschede and Frisch 1998, Musilová et al. 2015).

\section{CONCLUSIONS}

The Ephemeroptera data provided by the phylogenies and distributions available from South and Central America suggests the presence of several barriers that resulted in vicariant events. Many of these events are supported by more than one taxon. Although in some cases there are unique outcomes among the studied taxa, some of them were found also in other mayflies or insect groups. We consider that the information and analyses here provided are valuable for their comparison with other animal and even plant taxa, in pursue of the events that shaped the distribution of the South and Central American biota.

\section{ACKNOWLEDGMENTS}

We are grateful to many colleagues who shared their data and provided facilities to carry out the field and laboratory work in different parts of South America, or helped with material loans and discussion: María del Carmen Zúñiga, Daniel Emmerich, Frederico Salles, Lucimar G. Dias, Wills Flowers, Janice Peters. We thank Luciana Cristobal for Figures 1-4. Also, we would like to greatly acknowledge the permanent support and funding from CONICET (PUE099, PIP845).

\section{AUTHOR CONTRIBUTIONS}

All authors gathered the data, discussed the results and wrote the manuscript, CM analyzed the data and edited the figures.

\section{REFERENCES}

ALBA-TERCEDOR J AND MOSQUERA S. 1999. Caenis chamie: a new species from Colombia (Ephemeroptera: Caenidae). Pan-Pac Entomol 75: 61-67.

ALMEIDA F, NEVES B AND CARNEIRO C. 2000. The origin and evolution of the South American Platform. Earth Sci Rev 50: 77-111.

AMORIM DDS AND PIRES MRS. 1996. Neotropical biogeography and a method for maximum biodiversity estimation. Biodiversity in Brazil, a first approach. CNPq, São Paulo, p. 183-219.

ARIAS JS. 2010. VIP: Vicariance Inference Program Ver. 18. [Program, Code, and Documentation available at http://www. zmuc. dk/public/phylogeny/vip, Accessed September, 23, 2011].

ARIAS JS, SZUMIK CA AND GOLOBOFF PA. 2011. Spatial analysis of vicariance: a method for using direct geographical information in historical biogeography. Cladistics 27: 1-12.

BARBER-JAMES HM, GATTOLLIAT JL, SARTORI M AND HUBBARD MD. 2008. Global diversity of mayflies (Ephemeroptera, Insecta) in freshwater. Hydrobiologia 595: 339-350.

BISCONTI R, CANESTRELLI D, TENCHINI R, BELFIORE C, BUFFAGNI A AND NASCETTI G. 2016. Cryptic diversity and multiple origins of the widespread mayfly species group Baetis rhodani (Ephemeroptera: Baetidae) on northwestern Mediterranean islands. Ecol Evol 6: 7901-7910. 
BOLDRINI R, SANTOS GC AND OLIVEIRA DR. 2015. First record of the genus Lumahyphes Molineri, 2004 (Ephemeroptera: Leptohyphidae) from Brazil with description of a new species. Zootaxa 4013: 143-146.

BREWER-CARÍAS C AND AUDY M. 2011. Entrañas del mundo perdido. C. Brewer-Carías Ed., Caracas, Venezuela, $290 \mathrm{p}$.

BROOKS DR. 1990. Parsimony analysis in historical biogeography and coevolution: methodological and theoretical update. Syst Zool 39: 14-30.

BRUNDIN L. 1966. Transantarctic relationships and their significance, as evidence by chyronomid medges, with a monograph of the subfamilies Podonominae and Aphroteniinae and the austral Heptagyiae. Kungl. Svenska Vetenskapsakad. Handl. 11: 1-472.

CROIZAT L. 1958. Panbiogeography: Vols. 1, 2a, and $2 \mathrm{~b}$. Published by the author, Caracas.

CRUZ PV, SALLES FF AND HAMADA N. 2017. Phylogeny of Callibaetis (Ephemeroptera: Baetidae) based on morphology of nymphs and adults. Zool Scr 46: 138-149.

DAVIS JR. 1987. A new species of Farrodes (Ephemeroptera: Leptophlebiidae: Atalophlebiinae) from southern Texas. Proc Entomol Soc Wash 89: 407-416.

DEMOULIN G. 1966. Contribution à l'étude des Éphéméroptères du Surinam. Bull Inst R Sc N B-S 42: $1-22$.

DESAMORE A, VANDERPOORTEN A, LAENEN B, GRADSTEIN G AND KOK PJ. 2014. Biogeography of the Lost World (Pantepui region, northeastern South America): insights from bryophytes. Phytotaxa 9: 254265.

DOMÍNGUEZ E. 1999. Systematics, Cladistics and Biogeography of the American Genus Farrodes (Ephemeroptera: Leptophlebiidae: Atalophlebiinae). Zool J Linn Soc-Lond 126: 155-189.

DOMÍNGUEZ E AND DOS SANTOS DA. 2014. Coauthorship networks (and other contextual factors) behind the growth of taxonomy of South American Ephemeroptera: A scientometric approach. Zootaxa 3754: 59-85.

DOMÍNGUEZ E, MOLINERI C AND PETERS WL. 1996. Ephemeroptera from Central and South America: New species of the Farrodes bimaculatus group with a key for the males. Stud Neotrop Fauna E 31: 87-101.

DOMÍNGUEZ E AND ZÚÑIGA MC. 2009. First description of the larva of Farrodes roundsi (Traver) (Ephemeroptera: Leptophlebiidae: Atalophlebiinae) with comments on its phylogenetic relationships. Aquat Insect 31: 73-81.

DOMÍNGUEZ MC, AGRAIN FA, FLORES GE AND ROIGJUÑENT SA. 2016. Vicariance events shaping Southern South American insect distributions. Zool Scr 45: 504-511.

DOS SANTOS ET AL. 2018. Cold/Warm stenothermic freshwater macroinvertebrates along altitudinal and latitudinal gradients in Western South America: A modern approach to an old hypothesis with updated data. J Biogeogr 45: 1571-1581.

EATON AE. 1868. An outline of a re-arrangement of the genera of Ephemeridae. Entomol Mon Mag 6: 131-132.

EATON AE. 1881. An announcement of new genera of the Ephemeridae. Entomol Mon Mag 17: 191-197.

EBACH MC AND WILLIAMS DM. 2016. Dispersalism and neodispersalism. The Future of Phylogenetic Systematics: The Legacy of Willi Hennig, 86, 286 p.

EDMUND GF JR. 1972. Biogeography and evolution of Ephemeroptera. Ann Rev Entomol 17: 21-42.

ESBEN-PETERS EN T. 1912. New and little-known species of Ephemerida from Argentine. (Neuropt.). Deut Entomol Z 1912: 333-342.

FERRARI A. 2018. Biogeographical units matter. Aust Syst Bot 30: 391-402.

FLOWERS RW. 2009. Life was a beach: a panbiogeographic analysis of the cosmopolitan mayfly genus Choroterpes (Ephemeroptera: Leptophlebiidae: Atalophlebiinae). Aquat Insect 31: 585-593.

FLOWERS RW. 2012. A new species of Atopophlebia Flowers (Ephemeroptera: Leptophlebiidae) from western Ecuador with ecological and biogeographic notes on the genus. Zootaxa 3478: 11-18.

FLOWERS RW AND ÁVILA S. 2006. Biogeographical and ecological notes on the genus Tikuna Savage, Flowers, and Porras (Ephemeroptera: Leptophlebiidae) from Central and South America. Ent News 117: 133-138.

FROEHLICH CG. 1969. Caenis cuniana sp. n., a parthenogenetic mayfly. Beit Neotrop F 6: 103-108.

GAUCHER C ET AL. 2011. Mesoproterozoic evolution of the Río de la Plata Craton in Uruguay: at the heart of Rodinia? Int J Earth Sci 100: 273-288.

GATTOLLIAT JL, CAVALLO E, VUATAZ L AND SARTORI M. 2015. DNA barcoding of Corsican mayflies (Ephemeroptera) with implications on biogeography, systematics and biodiversity. Arthropod Syst Phylo 73: 3-18.

GOLOBOFF PA, FARRIS JS, KALLERSJO M, OXELMAN B, RAMIREZ MJ AND SZUMIK CA. 2003. Improvements to resampling measures of group support. Cladistics 19: 324-332.

GOLOBOFF PA, FARRIS JS AND NIXON K. 2008. TNT, a free program for phylogenetic analysis. Cladistics 24 : 774-786.

GONÇALVES IC, DA-SILVA ER AND NESSIMIAN JL. 2011. First record and new species of Tortopsis Molineri, 2010 (Ephemeroptera, Polymitarcyidae) from Brazil. Zootaxa 2866: 50-54.

HABERLE SG AND MASLIN MA. 1999. Late Quaternary vegetation and climate change in the Amazon Basin based on a 50,000 year pollen record from the Amazon Fan, ODP Site 932. Quaternary Res 51: 27-38. 
HAUSDORF B. 2002. Units in biogeography. Syst Biol 51: 648-652.

HAUSDORF B AND HENNIG C. 2003. Biotic element analysis in biogeography. Syst Biol 52: 717-723.

HENNIG W. 1966. Phylogenetic Systematics. University of Illinois Press, Urbana.

HOVENKAMP P. 1997. Vicariance events, not areas, should be used in biogeographical analysis. Cladistics 13: 67-79.

HOVENKAMP P. 2001. A direct method for the analysis of vicariance patterns. Cladistics 17: 260-265.

HUBBARD MD. 1975. The genus Asthenopodes Ulmer and its type species (Ephemeroptera: Polymitarcyidae). Fla Entomol 58: 111-112.

HUNN CA AND UPCHURCH P. 2001. The importance of time/space in diagnosing the causality of phylogenetic events: Towards a "chronobiogeographical" paradigm. Syst Biol 50: 391-407.

ITURRALDE-VINENT M AND MACPHEE RD. 1999. Paleogeography of the Caribbean region: implications for Cenozoic biogeography. B Am Mus Nat Hist 238: 1 - 95.

KEIGWIN LD. 1982. Isotopic paleooceanography of the Caribbean and east Pacific: role of Panama uplift in late Neogene time. Science 217: 350-352.

LIMA LR, MOLINERI C AND PINHEIRO U. 2015. A new species of Caenis Stephens, 1836 (Ephemeroptera: Caenidae) from Southern Brazil. Zootaxa 3941: 589-592.

LIMA LR, MOLINERI C, VIEIRA LM, PINHEIRO U AND SALLES FF. 2019. Phylogenetic analysis supports the monophyly of the South American mayfly genus Brasilocaenis Puthz, 1975 (Insecta: Ephemeroptera: Caenidae). Zool Anz 280: 78-94.

LIMA LR, SALLES FF AND PINHEIRO US. 2011. New species of Leptohyphidae (Ephemeroptera) from northeastern Brazil. Zootaxa 3050: 63-68.

LÖWENBERG NETO P. 2014. Neotropical region: a shapefile of Morrone's (2014) biogeographical regionalization. Zootaxa 3802: 300.

LUGO-ORTIZ CR AND MCCAFFERTY WP. 1996. Central American Tortopus (Ephemeroptera: Polymitarcyidae): A unique new species and new country records. Ent News 107: 23-27.

LUGO-ORTIZ CR AND MCCAFFERTY WP. 1998. Five new genera of Baetidae (Insecta: Ephemeroptera) from South America. Ann Limnol 34: 57-73.

MASSARIOL FC AND CRUZ PV. 2015. Oligoneuria (Yawari) anatina sp. nov. (Ephemeroptera: Oligoneuriidae) from the extreme north of Brazil. Zootaxa 4007: 242-250.

MCCAFFERTY WP. 1998. Ephemeroptera and the great American interchange. J N Am Benthol Soc 17: 1-20.

MCCAFFERTY WP. 2007. Moribaetis mimbresaurus, new species (Ephemeroptera: Baetidae): first representative of the genus north of Mexico. Proc Ent Soc Wash 109: 696699.
MESCHEDE M AND FRISCH W. 1998. A plate tectonic model for the Mesozoic and Early Cenozoic history of the Caribbean plate. Tectonophysics 296: 269-291.

MOLINERI C. 2004. Phylogeny of the AllenhyphesTraverhyphes group (Ephemeroptera: Leptohyphidae), with new subgenera, species and combinations. Tijdschr Entomol 147: 197-220.

MOLINERI C. 2010. A cladistic revision of Tortopus Needham and Murphy with description of the new genus Tortopsis (Ephemeroptera: Polymitarcyidae). Zootaxa 2481: 1-36.

MOLINERI C AND EMMERICH D. 2010. New species and new stage descriptions of Campsurus major species group (Polymitarcydae, Campsurinae), with first report of silkcase construction in mayfly nymphs. Aquat Insect 32: 265280.

MOLINERI C, GRILLET ME, NIETO C, DOMINGUEZ E AND GUERRERO E. 2011. New species and records for the mayfly families Caenidae, Leptohyphidae and Coryphoridae (Ephemeroptera, Pannota) from Venezuelan Guayana's Uplands. Zootaxa 2750: 39-50.

MOLINERI C AND SALLES FF. 2013. Phylogeny and biogeography of the ephemeral Campsurus Eaton (Ephemeroptera, Polymitarcyidae). Syst Ent 38: 265-277.

MOLINERI C AND SALLES FF. 2017. Review of selected species of Campsurus Eaton 1868 (Ephemeroptera: Polymitarcyidae), with description of eleven new species and a key to male imagos of the genus. Zootaxa 4300: 301-354.

MOLINERI C, SALLES FF AND BOLDRINI R. 2012. Tortopus Needham and Murphy and Tortopsis Molineri (Ephemeroptera, Polymitarcyidae) new species and new records from Brazil and Ecuador. Rev Bras Entomol 56: 463-467.

MOLINERI C, SALLES FF AND PETERS JG. 2015. Phylogeny and biogeography of Asthenopodinae with a revision of Asthenopus, reinstatement of Asthenopodes, and the description of the new genera Hubbardipes and Priasthenopus (Ephemeroptera, Polymitarcyidae). ZooKeys 478: 45-128.

MONTES C ET AL. 2012. Evidence for middle Eocene and younger land emergence in Central Panama: implications for Isthmus closure. Geol Soc Am Bull 124.

MORRONE JJ. 2014a. Biogeographical regionalization of the Neotropical region. Zootaxa 3782: 1-110.

MORRONE JJ. 2014b. Cladistic biogeography of the Neotropical region: identifying the main events in the diversification of the terrestrial biota. Cladistics 30: 202214.

MORRONE JJ AND CRISCI JV. 1995. Historical biogeography: introduction to methods. Annu Rev Ecol Syst 26: 373-401.

MUSILOVÁ Z, ŘÍČAN O, ŘÍČANOVÁ Š, JANŠTA P, GAHURA O AND NOVÁK J. 2015. Phylogeny and 
historical biogeography of trans-Andean cichlid fishes (Teleostei: Cichlidae). Vertebr Zool 65: 333-350.

NASCIMENTO JMC, SALLES FF AND HAMADA N. 2017. Systematics of Simothraulopsis Demoulin, 1966 (Ephemeroptera: Leptophlebiidae). Zootaxa 4285: 1-81.

NAVÁS L. 1932. Insectos de la Argentina. Rev Acad C Zaragoza 16: 87-120.

NAVÁS, L. 1934. Insectos suramericanos. Octava Serie. Rev Acad C Madrid 31: 9-28.

NEEDHAM JG AND MURPHY HE. 1924. Neotropical mayflies. Bull Lloyd Lib 24, Entl Series 4: 1-79.

NELSON G AND PLATNICK NI. 1981. Systematics and biogeography: Cladistics and vicariance. Columbia University Press, New York.

NIETO C. 2016. The Baetodes complex (Ephemeroptera: Baetidae), phylogeny, biogeography, and new species of Mayobaetis. Freshwat Sci 35: 55-64.

NIETO C AND DERKA T. 2012. A new species of the genus Spiritiops Lugo-Ortiz \& McCafferty (Ephemeroptera, Baetidae) from the Pantepui biogeographical province. Zootaxa 3256: 58-63.

O'DEA A, LESSIOS HA, COATES AG, EYTAN RI, RESTREPO-MORENO SA, CIONE AL AND STALLARD RF. 2016. Formation of the Isthmus of Panama. Sci Adv 2: e1600883.

OGDEN TH, GATTOLLIAT JL, SARTORI M, STANICZEK AH, SOLDÁN T AND WHITING MF. 2009. Towards a new paradigm in mayfly phylogeny (Ephemeroptera): combined analysis of morphological and molecular data. Syst Ent 34: 616-634.

OVERBECK GE, MÜLLER SC, FIDELIS A, PFADENHAUER J, PILLAR VD, BLANCO CC AND FORNECK ED. 2007. Brazil's neglected biome: the South Brazilian Campos. Perspect Plant Ecol 9: 101-116.

PETERS WL. 1971. A revision of the Leptophlebiidae of the West Indies (Ephemeroptera). Sm C Z 62: 1-48.

PESCADOR ML AND EDMUNDS JR GE. 1994. New genus of Oligoneuriidae (Ephemeroptera) from South America. Ann Ent Soc Amer 87: 263-269.

PICTET FJ. 1843. Histoire naturelle générale et particulière des insectes névroptères. Famille des Éphémérines. Chez J. Kessmann et Ab. Cherbuliz, Geneva.

PUTHZ V. 1975. Eine neue Caenidengattung aus dem Amazonasgebiet (Insecta: Ephemeroptera: Caenidae). Amazoniana 5: 411-415.

RAPELA CW, PANKHURST RJ, CASQUET C, FANNING CM, BALDO EG, GONZÁLEZ-CASADO JM AND DAHLQUIST J. 2007. The Río de la Plata craton and the assembly of SW Gondwana. Earth Sci Rev 83: 49-82.

REE RH AND SMITH SA. 2008. Maximum likelihood inference of geographic range evolution by dispersal, local extinction, and cladogenesis. Syst Biol 57: 4-14.
ŘÍČAN O, PIÁLEK L, ZARDOYA R, DOADRIO I AND ZRZAVÝ J. 2013. Biogeography of the Mesoamerican Cichlidae (Teleostei: Heroini): colonization through the GAARlandia land bridge and early diversification. J Biogeogr 40: 579-593.

RONQUIST F. 1997. Dispersal-vicariance analysis: a new approach to the quantification of historical biogeography. Syst Biol 46: 195-203.

ROSEN DE. 1978. Vicariant patterns and historical explanation in biogeography. Syst Zool 27: 159-188.

RULL V. 2004. Biogeography of the 'Lost World': a palaeoecological perspective. Earth Sci Rev 67: 125-137.

SALLES FF, ANGELI KB AND JACOBUS LM. 2016. Review of Waltzoyphius McCafferty and Lugo-Ortiz, 1995 and Zelusia Lugo-Ortiz and McCafferty, 1998 (Ephemeroptera: Baetidae). Zoosymposia 11: 174-204.

SALLES FF, SOARES ED, MASSARIOL FC AND FARIA LR. 2014. Oligoneuria Pictet: phylogenetic analysis and description of three new species from Brazil (Ephemeroptera: Oligoneuriidae). Syst Ent 39: 223-241.

SANMARTIN I AND RONQUIST F. 2004. Southern hemisphere biogeography inferred by event-based models: plant versus animal patterns. Syst Biol 53: 216-243.

SAVAGE HM. 1987. Biogeographic classification of the Neotropical Leptophlebiidae (Ephemeroptera) based upon geological centers of ancestral origin and ecology. Stud Neotrop Fauna E 22: 199-222.

SEKINÉ K, HAYASHI F AND TOJO K. 2013. Phylogeography of the East Asian polymitarcyid mayfly genus Ephoron (Ephemeroptera: Polymitarcyidae): a comparative analysis of molecular and ecological characteristics. Biol J Linn Soc 109: 181-202.

SELVAKUMAR C, SIVARAMAKRISHNAN K G, JACOBUS LM, JANARTHANAN S AND ARUMUGAM M. 2014. Two new genera and five new species of Teloganodidae (Ephemeroptera) from South India. Zootaxa 3846: 87-104.

SHIMANO Y, SALLES FF AND JUEN L. 2013. Study of the mayfly order Ephemeroptera (Insecta) in Brazil: a scienciometric review. Rev Bras Entomol 57: 359-364.

STANICZEK AH, BECHLY G AND GODUNKO RJ. 2011. Coxoplectoptera, a new fossil order of Palaeoptera (Arthropoda: Insecta), with comments on the phylogeny of the stem group of mayflies (Ephemeroptera). Insect Syst Evol 42: 101-138.

TRAVER JR. 1943. New Venezuelan mayflies. Bol Ent Venez 2: 79-98.

WILEY EO. 1988. Parsimony analysis and vicariance biogeography. Syst Zool 37: 271-290.

YU Y, HARRIS AJ AND HE X. 2010. S-DIVA (Statistical Dispersal-Vicariance Analysis): a tool for inferring biogeographic histories. Mol Phylogenet Evol 56: 848850 . 